\title{
Liposome Enhanced Detection of Amyloid Protein Aggregates
}

\author{
Istvan Kocsis ${ }^{\ddagger}$, Elena Sanna ${ }^{\ddagger}$ and Christopher A. Hunter* \\ Department of Chemistry, University of Cambridge, Lensfield Road, Cambridge CB2 1EW \\ (UK)

\section{Supplementary Information}




\section{General experimental details}

All the reagents and materials used in the synthesis of the compounds described below were bought from commercial sources, without prior purification. UV irradiations were performed using a UVP lamp model UVGL-58 ( $1 \times 365 \mathrm{~nm}$ tube, 6 wattss) and a UVP lamp model UVL-28 (2x365 nm tubes, 8 watts). Thin layer chromatography was carried out using silica gel 60F (Merck) on glass plates. Flash chromatography was carried out on an automated system (Combiflash Companion, Combiflash Rf+ or Combiflash Rf Lumen) using prepacked cartridges of silica ( $25 \mu$ or $50 \mu$ Puriflash ${ }^{\circledR}$ Columns). ${ }^{1} \mathrm{H}$ and ${ }^{13} \mathrm{C}$ NMR spectra were recorded on either a Bruker AV3400 or AV3500 spectrometer at $298 \mathrm{~K}$ unless specifically stated otherwise. Residual solvent was used as an internal standard. All chemical shifts are quoted in ppm on the $\delta$ scale and the coupling constants expressed in $\mathrm{Hz}$. +- Signal splitting patterns are described as follows: $\mathrm{s}$ (singlet), d (doublet), $\mathrm{t}$ (triplet), q (quartet), $\mathrm{m}$ (multiplet). UV-Vis spectroscopic data were recorded using a Cary 60 spectrophotometer (Agilent). Fluorescence spectroscopic data were recorded using a Cary Eclipse fluorescence spectrophmeter (Agilent). FT-IR spectra were recorded on a PerkinElmer Spectrum One FT-IR spectrometer equipped with a ATR cell. Preparative HPLC were performed in an Agilent HP1100. The LCMS analysis of samples was performed using a Waters Acquity H-Class UPLC coupled with a single quadrupole Waters SQD2 or a Waters Xevo G2-S bench top QTOF machine.

\section{Synthesis and characterization of products}
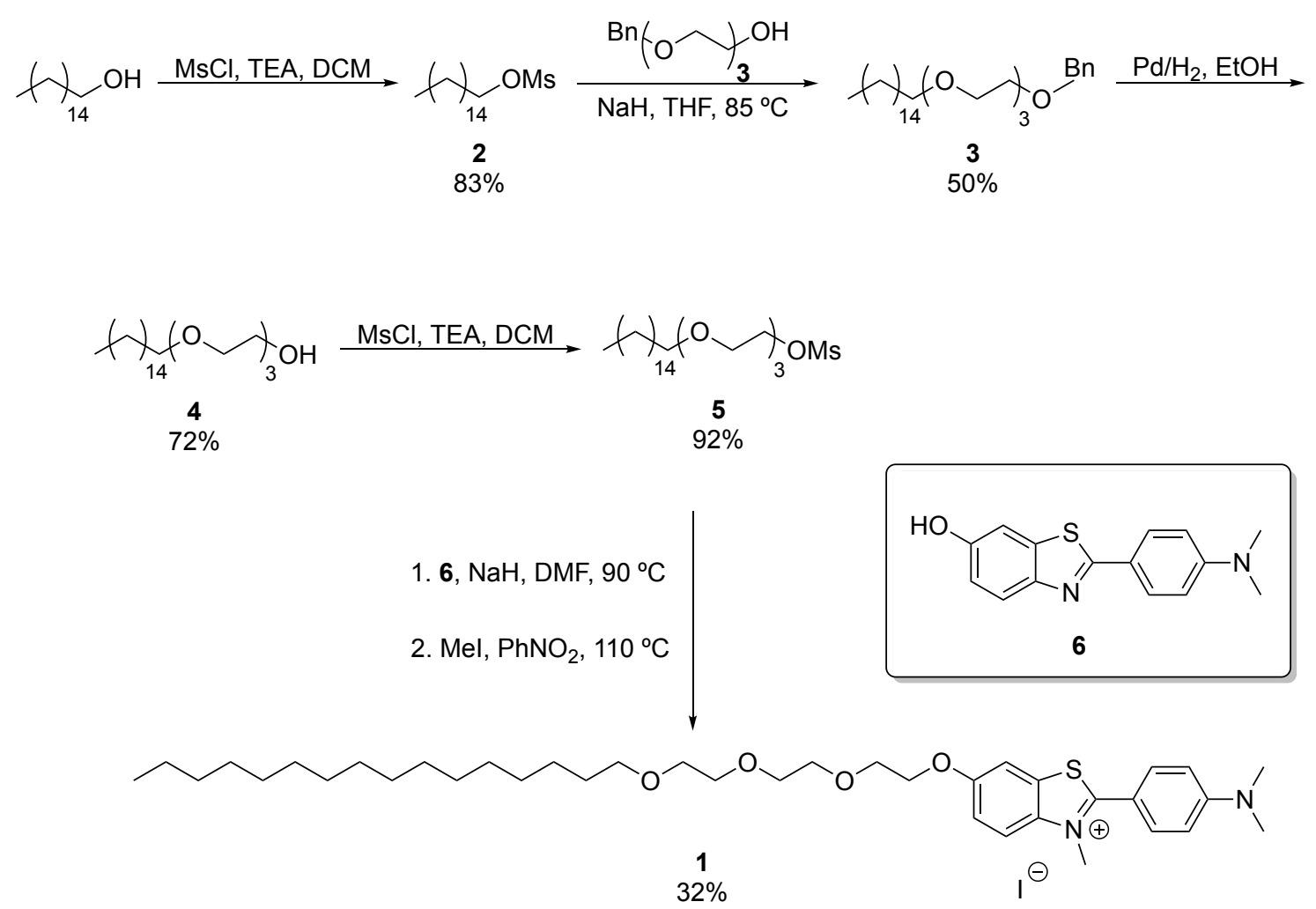


\section{2-(4-(dimethylamino)phenyl)benzo[d]thiazol-6-ol (6)}<smiles>CN(C)c1ccc(-c2nc3ccc(O)cc3s2)cc1</smiles>

The product was synthesized following a previously reported procedure. ${ }^{1}$

\section{Preparation of hexadecyl methanesulfonate (2)}

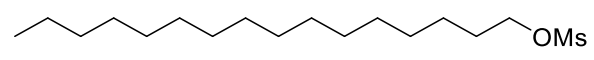

The product was obtained by modification of a previously reported procedure. ${ }^{2} 0.25 \mathrm{~mL}(3.22$ $\mathrm{mmol}$ ) of methanesulfonyl chloride were added dropwise at $-40{ }^{\circ} \mathrm{C}$ to a solution of $0.5 \mathrm{~g}(2.062$ mmol) of hexadecan-1-ol and $0.6 \mathrm{~mL}(4.29 \mathrm{mmol})$ of TEA in $20 \mathrm{~mL}$ of anhydrous $\mathrm{CH}_{2} \mathrm{Cl}_{2}$. The resulting solution was stirred at room temperature for $3 \mathrm{~h}$. Then, the solution was washed with $15 \mathrm{~mL} \mathrm{HCl} 1 \mathrm{M}$. The aqueous layer was re-extracted with $\mathrm{CH}_{2} \mathrm{Cl}_{2}(2 \times 10 \mathrm{~mL})$. The combined organic fractions were dried over anhydrous $\mathrm{Na}_{2} \mathrm{SO}_{4}$, filtered, and concentrated. The residue was purified by column chromatography (silica, PE:EtOAc (0-100 \%) then, EtOAc:MeOH 0-50 \%). The product was obtained as white solid $(0.551 \mathrm{~g}, 83 \%$ yield).

m.p.: $53.1-54.0{ }^{\circ} \mathrm{C} .{ }^{1} \mathrm{H} \mathrm{NMR}\left(\mathrm{CDCl}_{3}, 400 \mathrm{MHz}\right) \delta(\mathrm{ppm}): 4.22(\mathrm{t}, J=6.6 \mathrm{~Hz}, 2 \mathrm{H}), 3.00(\mathrm{~s}, 3 \mathrm{H}), 1.82$ $-1.68(\mathrm{~m}, 2 \mathrm{H}), 1.26(\mathrm{~s}, 24 \mathrm{H}), 0.88(\mathrm{t}, J=6.7 \mathrm{~Hz}, 3 \mathrm{H}) .{ }^{13} \mathrm{C} \mathrm{NMR}\left(\mathrm{CDCl}_{3}, 100.6 \mathrm{MHz}\right) \delta(\mathrm{ppm}): 70.3$, $37.5,32.0,29.8,29.8,29.7,29.6,29.5,29.5,29.2,29.1,25.5,22.8,14.2$.

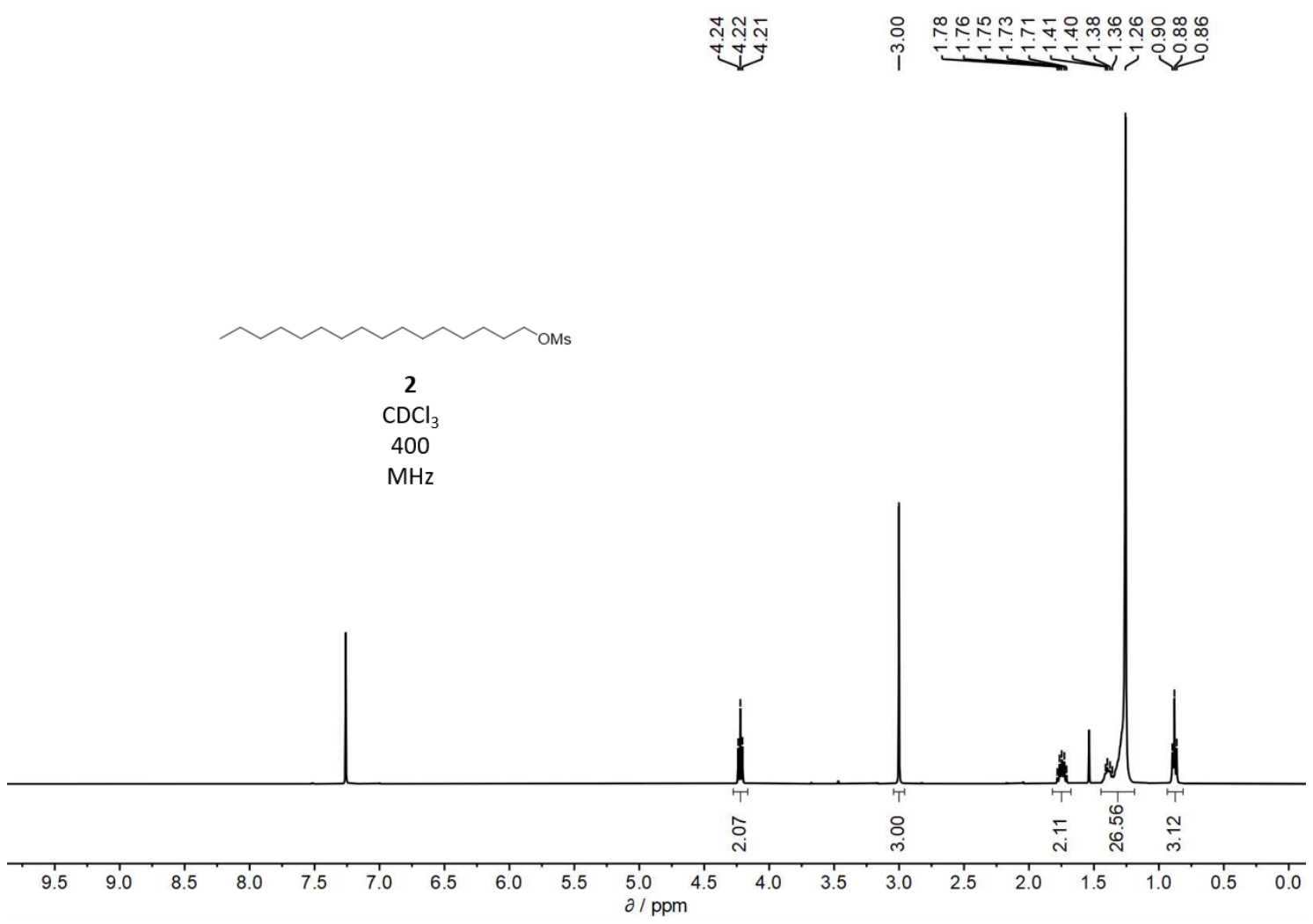




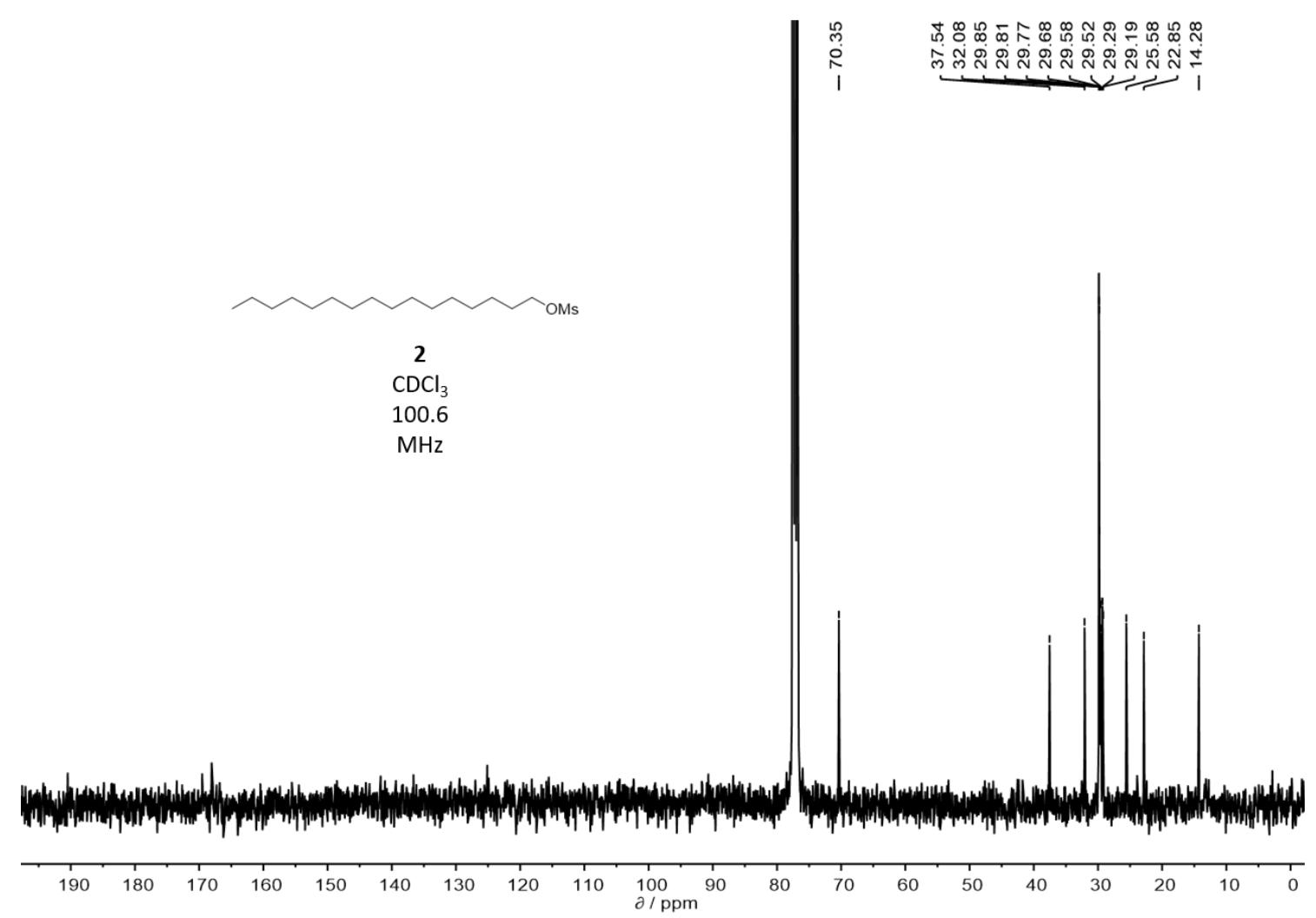

Preparation of 1-phenyl-2,5,8,11-tetraoxaheptacosane (3)

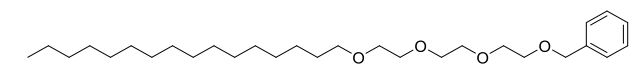

$0.55 \mathrm{~mL}(1.2 \mathrm{mmol})$ of trietyleneglycol monobenzyl ether were dissolved in $15 \mathrm{~mL}$ of $\mathrm{THF}_{(\mathrm{anh})}$. $0.915 \mathrm{~g}(22.88 \mathrm{mmol})$ of $\mathrm{NaH} 60 \%$, and $0.55 \mathrm{~g}(1.716 \mathrm{mmol})$ of 2 in $5 \mathrm{~mL}$ of $\mathrm{THF}_{(\text {anh) }}$ were added sequentially. The resulting solution was refluxed overnight. Then, $15 \mathrm{~mL}$ of $\mathrm{HCl} 1 \mathrm{M}$ and $5 \mathrm{~mL}$ of brine were added, and the resulting solution was extracted with DCM $(3 \times 10 \mathrm{~mL})$. The combined organic layers were dried over $\mathrm{Na}_{2} \mathrm{SO}_{4}$, filtered and concentrated. The product was purified by flash chromatography (silica, PE:EtOAc 0-100 \% then, EtOAc:MeOH 0-50 \%). The product was obtained as orange-yellow oil ( $0.395 \mathrm{~g}, 50 \%$ yield).

${ }^{1} \mathrm{H} \mathrm{NMR}\left(\mathrm{CDCl}_{3}, 400 \mathrm{MHz}\right) \delta(\mathrm{ppm}): 7.44-7.27(\mathrm{~m}, 5 \mathrm{H}), 4.57(\mathrm{~s}, 2 \mathrm{H}), 3.66(\mathrm{~d}, J=9.6 \mathrm{~Hz}, 10 \mathrm{H}), 3.59$ $-3.54(\mathrm{~m}, 2 \mathrm{H}), 3.44(\mathrm{t}, J=6.8 \mathrm{~Hz}, 2 \mathrm{H}), 1.57(\mathrm{t}, J=7.0 \mathrm{~Hz}, 2 \mathrm{H}), 1.25(\mathrm{~s}, 26 \mathrm{H}), 0.88(\mathrm{t}, J=6.7 \mathrm{~Hz}$, $3 \mathrm{H}) .{ }^{13} \mathrm{C} \mathrm{NMR}\left(\mathrm{CDCl}_{3}, 100.6 \mathrm{MHz}\right) \delta(\mathrm{ppm}): 138.3,128.3,127.7,127.5,73.2,71.5,70.6,70.6,70.0$, 69.4, 31.9, 29.7, 29.6, 29.6, 29.6, 29.5, 29.3, 26.1, 22.7, 14.1. HRMS (ASAP-TOF) m/z: [M+H] ${ }^{+}$calc. $\mathrm{C}_{29} \mathrm{H}_{53} \mathrm{O}_{4}$ 465.3944; exp. 465.3939. IR (ATR, $\left.\mathrm{cm}^{-1}\right)$ : 2922, 2852, 1455, 1352, 1299, 1247, 1211, 1106, 1043, 1029, 945, 883, 735, 698. 


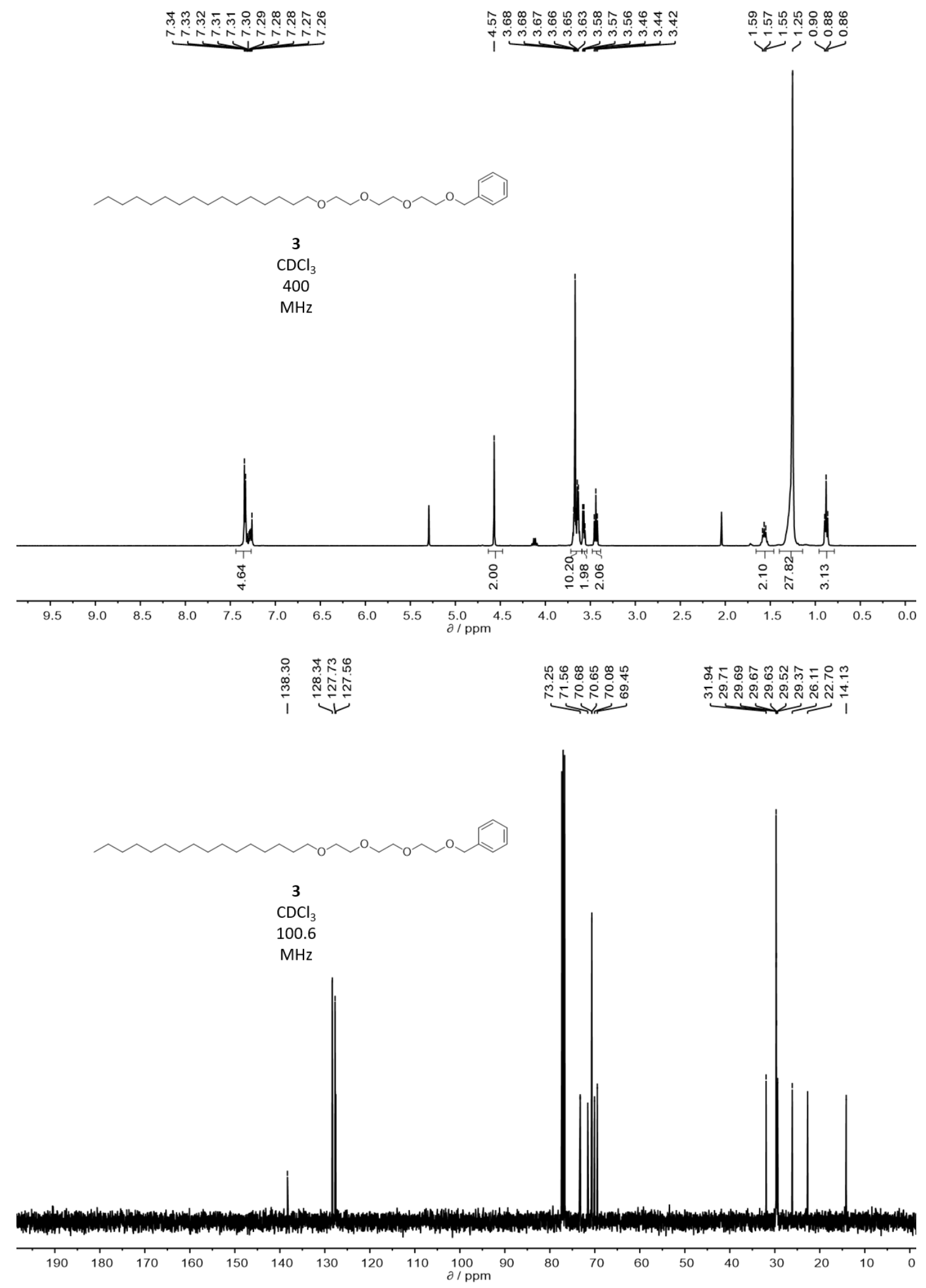




\section{Preparation of 2-(2-(2-(hexadecyloxy)ethoxy)ethoxy)ethan-1-ol (4)}

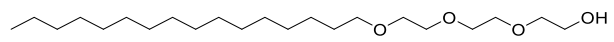

$0.395 \mathrm{~g}(0.85 \mathrm{mmol})$ of 3 and $0.317 \mathrm{~g}(0.297 \mathrm{mmol})$ of $\mathrm{Pd} / \mathrm{C} 10 \%$ were dissolved in $20 \mathrm{~mL}$ of $\mathrm{EtOH}_{\text {(abs) }}$ and the suspension was hydrogenated overnight. Then, the mixture was filtered through celite and washed with $\mathrm{EtOH}$. The solvent was removed under reduced pressure. The product was obtained as yellow oil $(0.233 \mathrm{~g}, 72 \%$ yield).

${ }^{1} \mathrm{H} \mathrm{NMR}\left(\mathrm{CDCl}_{3}, 400 \mathrm{MHz}\right) \delta(\mathrm{ppm}): 3.90-3.51(\mathrm{~m}, 12 \mathrm{H}), 3.45(\mathrm{t}, J=6.8 \mathrm{~Hz}, 2 \mathrm{H}), 2.49(\mathrm{~s}, 1 \mathrm{H}), 1.58$ $(\mathrm{p}, J=6.9 \mathrm{~Hz}, 2 \mathrm{H}), 1.25(\mathrm{~s}, 26 \mathrm{H}), 0.88(\mathrm{t}, J=6.7 \mathrm{~Hz}, 3 \mathrm{H}) .{ }^{13} \mathrm{C} \mathrm{NMR}\left(\mathrm{CDCl}_{3}, 100.6 \mathrm{MHz}\right) \delta(\mathrm{ppm}):$ 72.4, 71.6, 70.6, 70.4, 70.0, 61.8, 31.9, 29.7, 29.6, 29.5, 29.3, 26.0, 22.7, 14.1. HRMS (ESI-TOF) $\mathrm{m} / \mathrm{z}$ : $[\mathrm{M}+\mathrm{Na}]^{+}$calc. $\mathrm{C}_{22} \mathrm{H}_{46} \mathrm{O}_{4} \mathrm{Na}$ 397.3294; exp. 397.3285. IR (ATR, $\left.\mathrm{cm}^{-1}\right): 2919,2851,1472,1342$, $1328,1265,1169,974,945,853,738,705,543,530,520,444$.

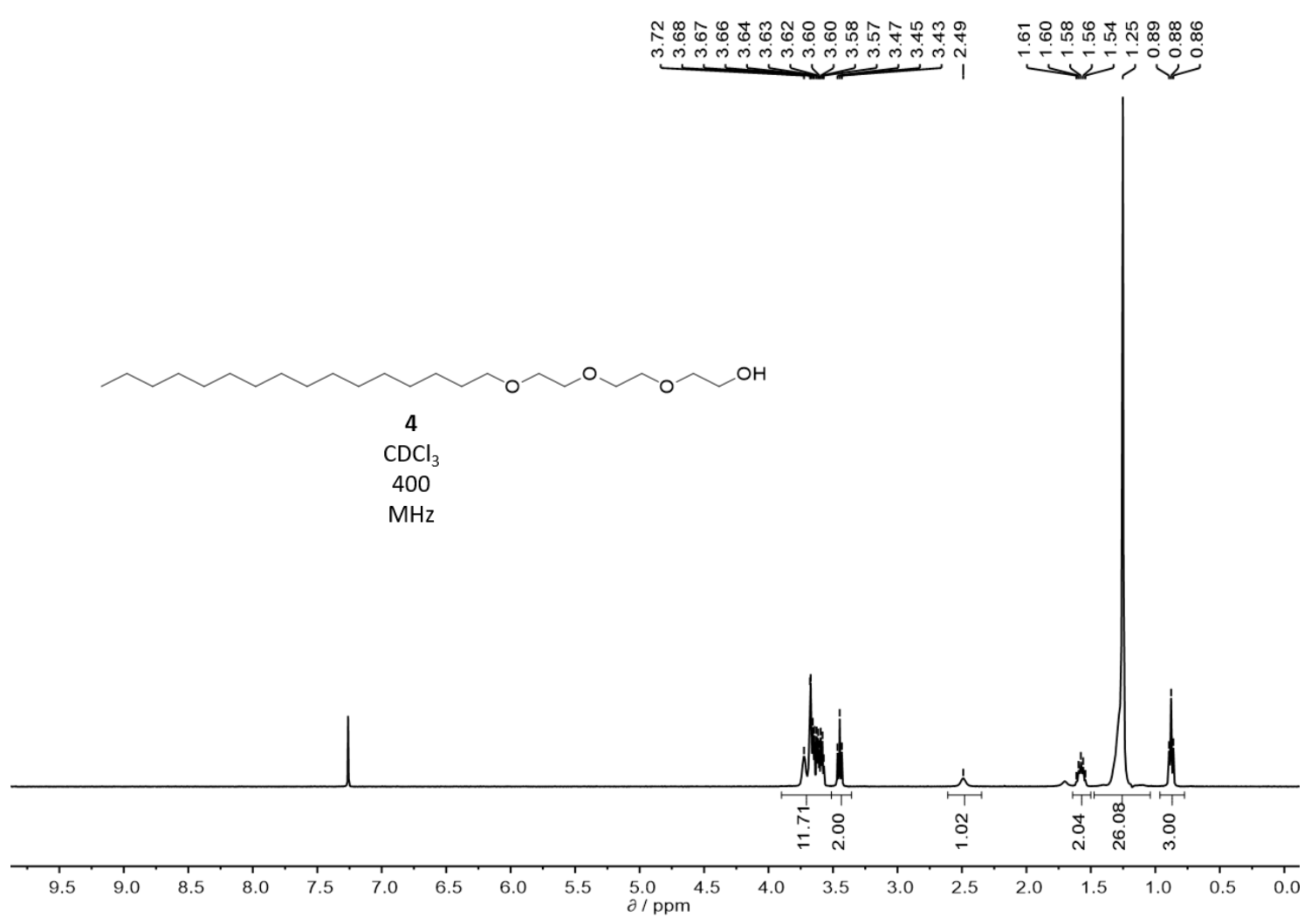




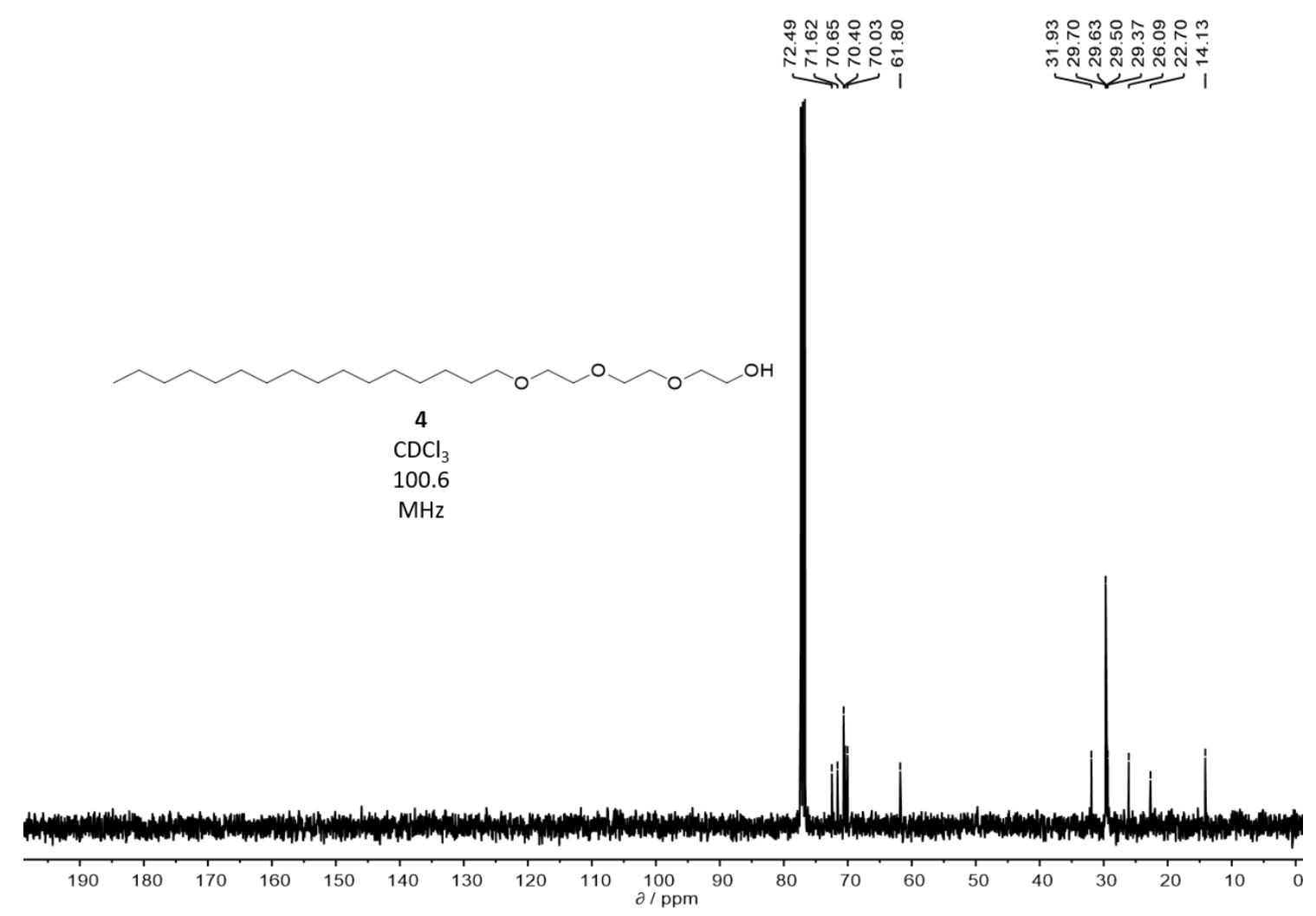

Preparation of 2-(2-(2-(hexadecyloxy)ethoxy)ethoxy)ethyl methanesulfonate (5)

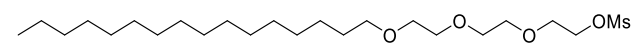

$0.055 \mathrm{~mL}(0.706 \mathrm{mmol})$ of methanesulfonyl chloride were added dropwise at $-40{ }^{\circ} \mathrm{C}$ to a solution of $0.23 \mathrm{~g}(0.614 \mathrm{mmol})$ of 4 and $0.171 \mathrm{~mL}(1.228 \mathrm{mmol})$ of TEA in $20 \mathrm{~mL}$ of anhydrous $\mathrm{CH}_{2} \mathrm{Cl}_{2}$. The resulting solution was stirred at room temperature for $4 \mathrm{~h}$. Then, the solution was washed with $10 \mathrm{~mL} \mathrm{HCl} 1 \mathrm{M}$. The aqueous layer was re-extracted with $\mathrm{CH}_{2} \mathrm{Cl}_{2}(2 \times 10 \mathrm{~mL})$. The combined organic fractions were dried over anhydrous $\mathrm{Na}_{2} \mathrm{SO}_{4}$, filtered, and concentrated. The residue was purified by column chromatography (silica, PE:EtOAc (0-50\%). The product was obtained as yellow oil ( $0.257 \mathrm{~g}, 92 \%$ yield).

${ }^{1} \mathrm{H} \mathrm{NMR}\left(\mathrm{CDCl}_{3}, 400 \mathrm{MHz}\right) \delta(\mathrm{ppm}): 4.44-4.33(\mathrm{~m}, 2 \mathrm{H}), 3.82-3.73(\mathrm{~m}, 2 \mathrm{H}), 3.72-3.59(\mathrm{~m}, 6 \mathrm{H})$, $3.44(\mathrm{t}, J=6.8 \mathrm{~Hz}, 2 \mathrm{H}), 3.07(\mathrm{~s}, 3 \mathrm{H}), 1.57(\mathrm{p}, J=6.9 \mathrm{~Hz}, 2 \mathrm{H}), 1.25(\mathrm{~m}, 26 \mathrm{H}), 0.88(\mathrm{t}, J=6.5 \mathrm{~Hz}, 3 \mathrm{H})$. ${ }^{13} \mathrm{C} \mathrm{NMR}\left(\mathrm{CDCl}_{3}, 100.6 \mathrm{MHz}\right) \delta(\mathrm{ppm}): 71.7,70.8,70.8,70.7,70.2,69.4,69.2,37.9,32.0,29.8$, 29.8, 29.8, 29.6, 29.5, 26.2, 22.8, 14.3. HRMS (ASAP-TOF) m/z: [M+H] ${ }^{+}$calc. $\mathrm{C}_{23} \mathrm{H}_{49} \mathrm{O}_{6} \mathrm{~S} 453.3250$; exp. 453.3247. IR (ATR, $\mathrm{cm}^{-1}$ ): 2920, 2852, 1466, 1351, 1267, 1249, 1174, 1108, 1018, 972, 919, $798,734,527,456,418$. 


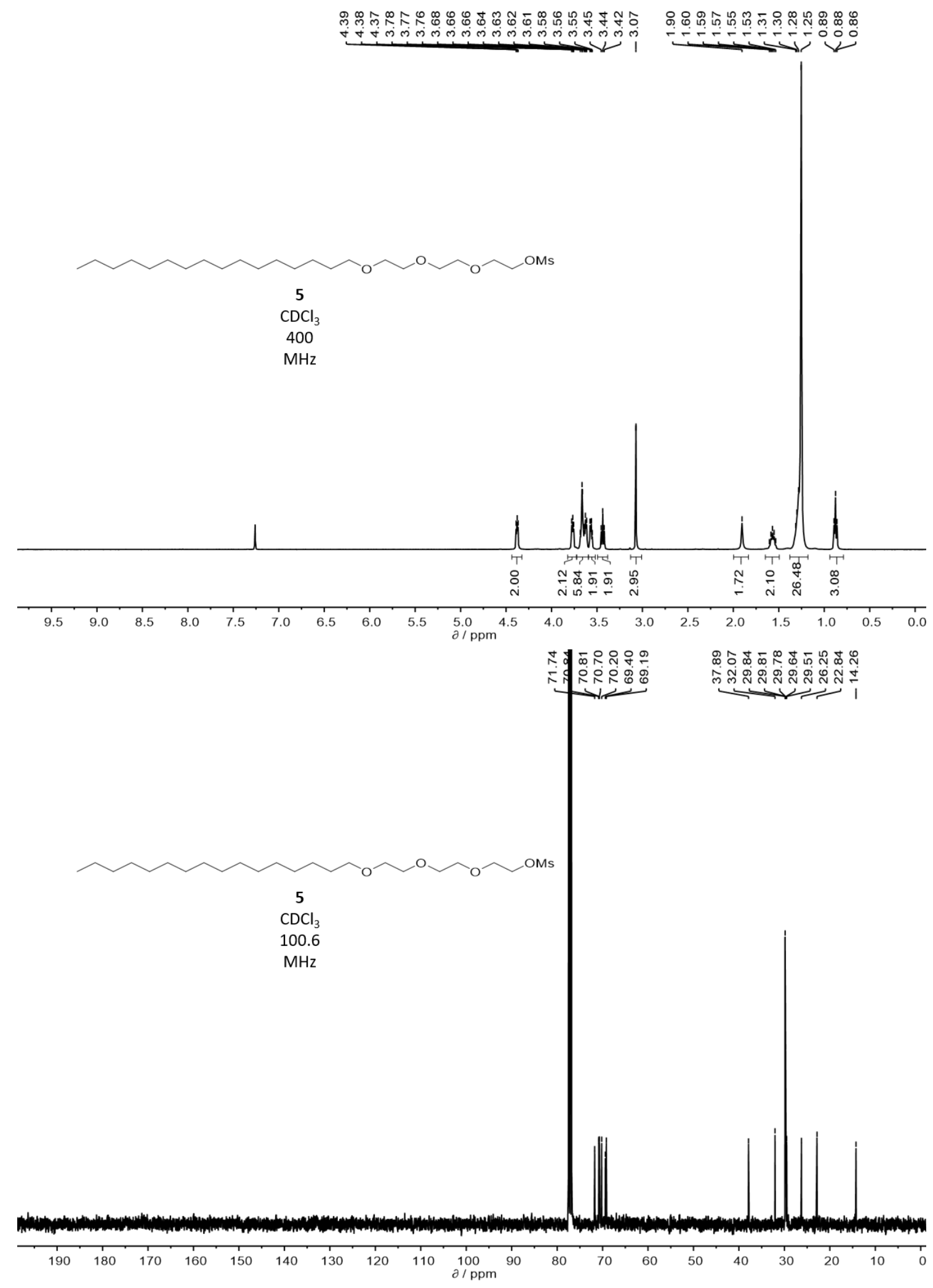




\section{Preparation of compound 1}

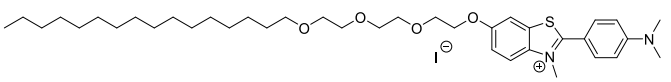

$72 \mathrm{mg}(0.265 \mathrm{mmol})$ of 6 and $97 \mathrm{mg}(2.43 \mathrm{mmol})$ of $\mathrm{NaH} 60 \%$ were dissolved in $4 \mathrm{~mL}$ of $\mathrm{DMF}_{(\mathrm{anh})}$. $0.1 \mathrm{~g}(0.221 \mathrm{mmol})$ of 5 in $10 \mathrm{~mL}$ of $\mathrm{DMF}_{(\text {anh) }}$ were added. The resulting suspension was stirred at $90{ }^{\circ} \mathrm{C}$ overnight. Then, $10 \mathrm{~mL}$ of $\mathrm{NH}_{4} \mathrm{Cl}_{\text {(sat) }}$ were added and the resulting solution was extracted with DCM $(3 \times 10 \mathrm{~mL})$. The combined organic layers were washed with LiCl $5 \%(3 \times 10 \mathrm{~mL})$, dried over $\mathrm{Na}_{2} \mathrm{SO}_{4}$, filtered and concentrated. The crude products were separated by semipreparative HPLC (Hichrom, MeCN: $\mathrm{H}_{2} \mathrm{O} 5-100 \% 8 \mathrm{~min}$ then, MeCN 100\% $5 \mathrm{~min}$ ), and the alkoxybenzothiazole was obtained as orange-brown oil and used directly. $50 \mathrm{mg}(0.08 \mathrm{mmol})$ of the alkoxybenzothiazole and $50 \mu \mathrm{L}(0.798 \mathrm{mmol})$ of Mel were added to in $3.3 \mathrm{~mL}$ of $\mathrm{PhNO}_{2}$ in a closed microwave vial. The resulting solution was stirred at $110^{\circ} \mathrm{C}$ two days. Then, $5 \mathrm{~mL}$ of PE and $5 \mathrm{~mL}$ of $\mathrm{H}_{2} \mathrm{O}$ were added, and the resulting solution was extracted with DCM $(3 \times 10 \mathrm{~mL})$ and EtOAc $(3$ $x 10 \mathrm{~mL}$ ). The aqueous layer was concentrated. The product was purified by semipreparative HPLC (Hichrom, MeCN: $\mathrm{H}_{2} \mathrm{O} 5-100 \% 8 \mathrm{~min}$ then, MeCN 100\% $5 \mathrm{~min}$ ). The product was obtained as yellow oil ( $26 \mathrm{mg}, 42 \%$ yield).

${ }^{1} \mathrm{H} \mathrm{NMR}\left(\mathrm{CDCl}_{3}, 400 \mathrm{MHz}\right) \delta(\mathrm{ppm}): 7.98(\mathrm{~d}, J=9.3 \mathrm{~Hz}, 1 \mathrm{H}), 7.84(\mathrm{~d}, J=9.1 \mathrm{~Hz}, 2 \mathrm{H}), 7.79(\mathrm{~d}, J=2.4$ $\mathrm{Hz}, 1 \mathrm{H}), 7.39(\mathrm{dd}, J=9.3,2.4 \mathrm{~Hz}, 1 \mathrm{H}), 6.87(\mathrm{~d}, J=9.1 \mathrm{~Hz}, 2 \mathrm{H}), 4.50(\mathrm{~s}, 3 \mathrm{H}), 4.34-4.26(\mathrm{~m}, 2 \mathrm{H})$, $3.97-3.90(\mathrm{~m}, 2 \mathrm{H}), 3.82-3.75(\mathrm{~m}, 2 \mathrm{H}), 3.75-3.71(\mathrm{~m}, 2 \mathrm{H}), 3.68(\mathrm{dd}, J=5.9,3.6 \mathrm{~Hz}, 3 \mathrm{H}), 3.64-$ $3.57(\mathrm{~m}, 2 \mathrm{H}), 3.47(\mathrm{t}, J=6.8 \mathrm{~Hz}, 2 \mathrm{H}), 3.18(\mathrm{~s}, 6 \mathrm{H}), 1.58(\mathrm{~s}, 2 \mathrm{H}), 1.27(\mathrm{~s}, 26 \mathrm{H}), 0.90(\mathrm{t}, J=6.8 \mathrm{~Hz}$, $3 \mathrm{H}) .{ }^{13} \mathrm{C} \mathrm{NMR}\left(\mathrm{CDCl}_{3}, 100.6 \mathrm{MHz}\right) \delta$ (ppm): 171.2, 158.9, 154.0, 136.9, 132.6, 129.8, 119.6, 117.6, 112.4, 111.0, 107.4, 71.7, 70.9, 70.8, 70.7, 70.1, 69.5, 68.9, 40.3, 40.0, 32.0, 29.8, 29.8, 29.8, 29.7, 29.6, 29.5, 26.2, 22.8, 14.2. HRMS (ASAP-TOF) m/z: [M+H] ${ }^{+}$calc. $\mathrm{C}_{38} \mathrm{H}_{61} \mathrm{~N}_{2} \mathrm{O}_{4} \mathrm{~S}$ 641.4352; exp. 641.4343. IR (ATR, cm $\left.{ }^{-1}\right): 3463,2920,2852,1608,1506,1482,1467,1404,1387,1351,1333$, $1303,1272,1236,1119,1068,950,825,801,421$.

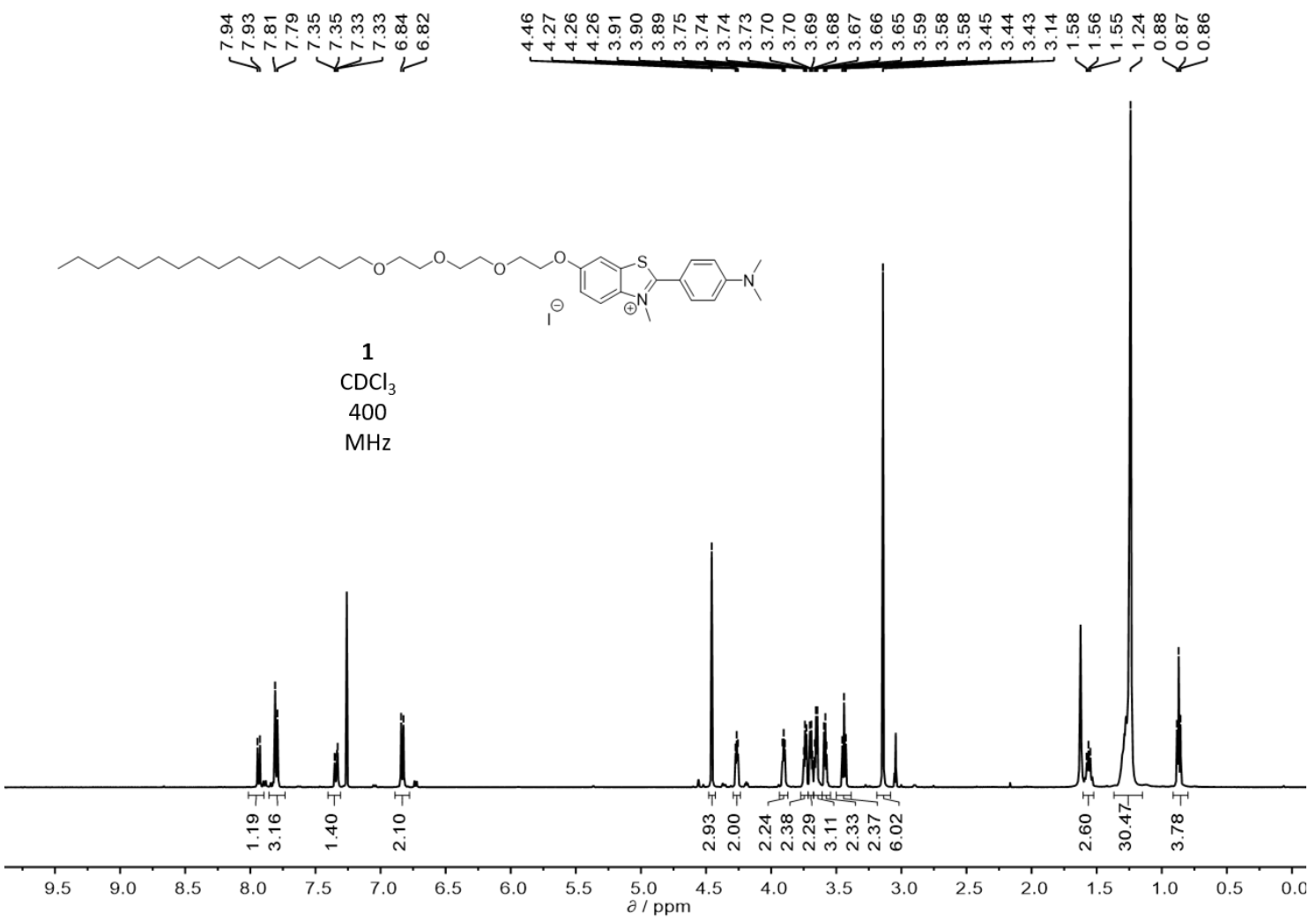




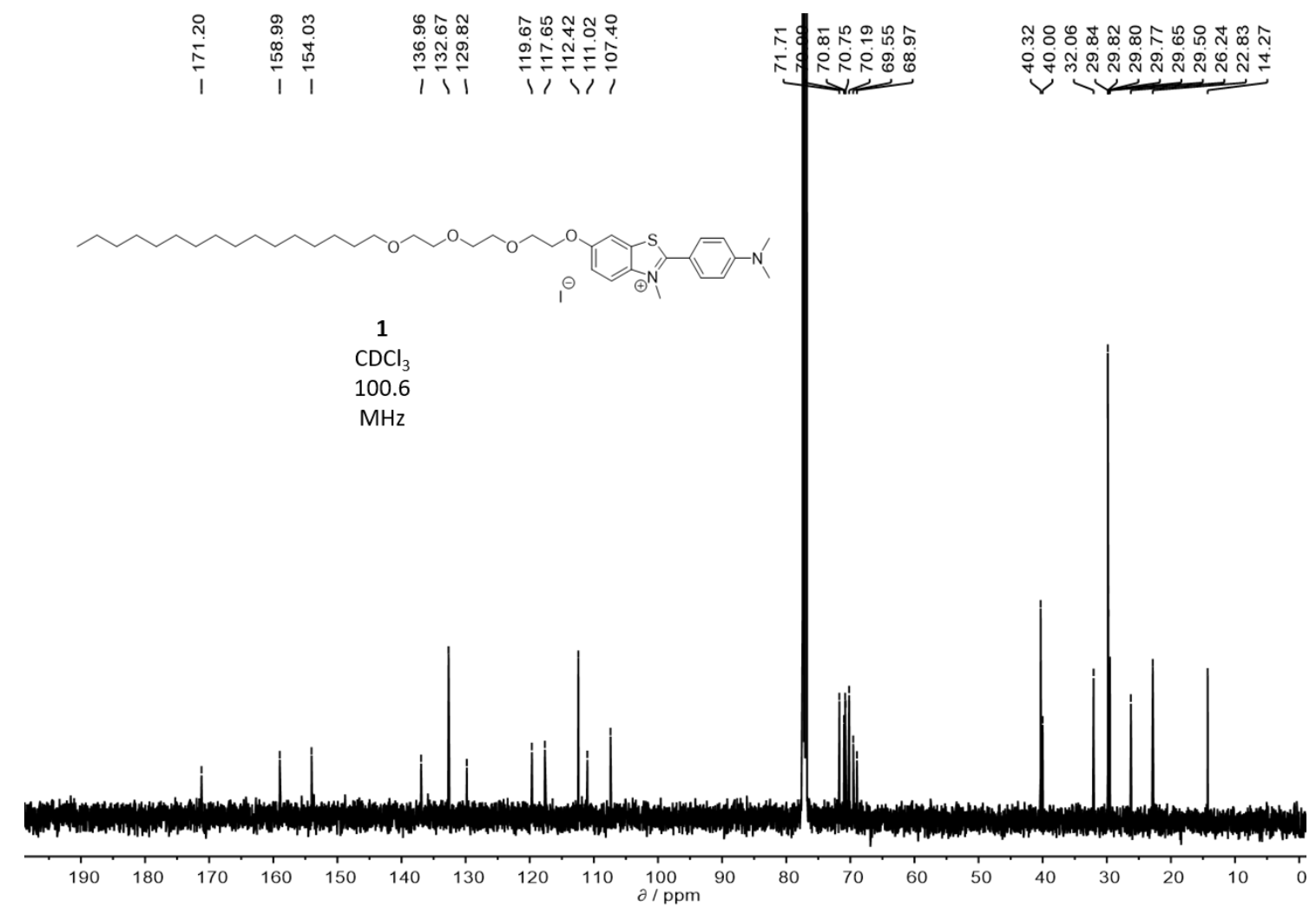




\section{HPLC characterization of the product}

The experiments were carried out on a Waters Acquity H-classUPLCcoupled with a single quadrupole Waters SQD2. ACQUITY UPLC CSH C18 Column, 130Å, $1.7 \mu \mathrm{m}, 2.1 \mathrm{~mm}$ X 50 $\mathrm{mm}$ was used as the UPLC column. The conditions of the UPLC method are as follows: Solvent A: Water $+0.1 \%$ Formic acid; Solvent B: Acetonitrile $+0.1 \%$ Formic acid; Gradient of $0-2$ minutes $5 \%-100 \% B+1$ minute $100 \%$ B with re-equilibration time of 2 minutes. Flow rate: 0.6 $\mathrm{ml} / \mathrm{min}$; Column temperature of $40{ }^{\circ} \mathrm{C}$; Injection volume of $2 \mu \mathrm{L}$. The signal was monitored at $354 \mathrm{~nm}$.

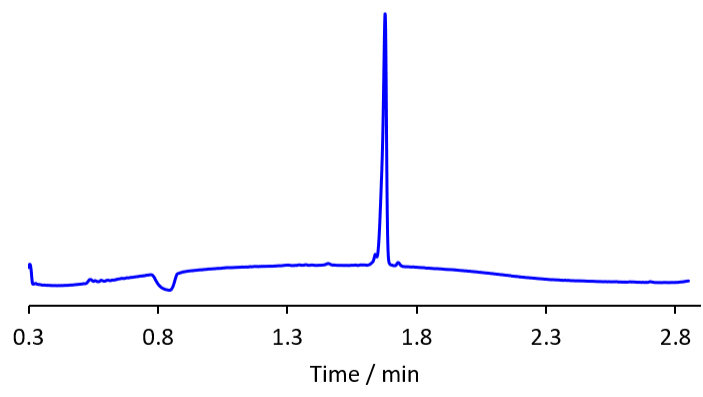

Figure S1. HPLC trace of compound 1.

\section{Protein aggregation procedure}

$\alpha$-synuclein protein aggregation was performed following a previously reported procedure. ${ }^{1}$ Sonicated short fibrils were produced by incubating a $500 \mu$ l solution of $\alpha$-synuclein at $173 \mu \mathrm{M}$ concentration in PBS buffer at $40{ }^{\circ} \mathrm{C}$ for $72 \mathrm{~h}$ under stirring with a Teflon bar on an heat plate. The fibrils were sonicated between 20 and 30 seconds using a probe sonicator (Bandelin, Sonopuls HD 2070), using $10 \%$ maximum power and $50 \%$ cycles three times. The sample was then separated into aliquotes and freeze at $-20{ }^{\circ} \mathrm{C}$ until required.

\section{Vesicle preparation}

Vesicles were prepared from 1,2-dioleoyl-sn-glycero-3-phosphocholine (DOPC chloroform solution). For vesicles containing the probe, the corresponding amount 6 was added to the lipid solution. The solvent was evaporated under a stream of nitrogen and the residue dried for $2 \mathrm{~h}$ under high vacuum. The resulting thin film was hydrated in 500 uL of PBSX1 buffer. After hydration, the suspension was subjected to five freeze-thaw cycles (liquid nitrogen, water at room temperature). The obtained suspension was extruded 21 times through a $200 \mathrm{~nm}$ polycarbonate membrane. The vesicle suspension was separated from any extravesicular content by size exclusion chromatography using prepacked Sephadex G-25M columns (prequilibrated with PBSX1, as mobile phase). The obtained solution was diluted to the final concentration of $1 \mathrm{mM}$ and used as stock solution within the day. 


\section{Fluorescence titrations}

For a typical titration, stock solutions of $1(1 \mathrm{mM})$ in DMSO and $\alpha$-Synuclein $(10 \mu \mathrm{M})$ in PBS $1 \mathrm{X}$ $(\mathrm{pH}$ 7.4) were prepared. The solutions for the titration were prepared by dilution of the corresponding amount of stock solutions in PBS 1X. For the titrations of vesicles loaded with different amounts of 1 , the concentration of $\alpha$-Synuclein was $0.1 \mu \mathrm{M}$ with increasing amounts of DOPC/1 ([1] $=0-2 \mu \mathrm{M})$. For the titrations of 1 , the concentration of $\alpha$-Synuclein was $0.5 \mu \mathrm{M}$ with increasing amounts of DOPC/1 $([\mathbf{1}]=0-100 \mathrm{nM})$. In all cases, the concentration of protein was constant during the titrations.

Titrations were carried out at $25^{\circ} \mathrm{C}$ using $20 \mathrm{~nm}$ slits. The PMT voltage used for titrations with 1 was midium, while for DOPC/1 it was high. Initial volume was $0.4 \mathrm{~mL}$. After each addition, the solution was lead to equilibrate at least 180 minutes and its fluorescence spectra registered. The excitation wavelength was $440 \mathrm{~nm}$ monitoring the emission at $490 \mathrm{~nm}$.

\section{Binding isotherms}

The fluorescence spectra were analysed using a Microsoft Excel spreadsheet to fit the changes in fluorescence intensity at fixed wavelengths to a 1:1 binding isotherm by optimizing the association constant and brightness $(\varepsilon \phi)$ of the free and bound guest using purpose written VBA macros. Equation 1 describes how the emission intensity (I) is related to the concentration of free and bound dye.

$I=\epsilon_{f} \phi_{f}[$ free $]+\epsilon_{b} \phi_{b}[$ bound $] \quad$ Eq 1

where $\epsilon_{f} \phi_{f}$ and $\epsilon_{b} \phi_{b}$ are product of the UV-vis absorption extinction coefficient and the fluorescence quantum yield for the free and bound dye respectively.

Equations 2 and 3 describe how the free and bound concentrations of dye are related to the dissociation constant for binding to the protein $\left(K_{d}\right)$.

$[L]=[$ free $]+[$ bound $] \quad$ Eq 2

$[$ bound $]=\frac{K_{d}+[L]+[S]-\sqrt{\left(K_{d}+[L]+[S]\right)^{2}-4[L][S]}}{2} \quad$ Eq 3

where $[\mathrm{L}]$ and $[\mathrm{S}]$ are the total concentrations of dye and protein binding sites respectively.

The concentration of protein binding sites is an unknown, which was allowed to vary during the fitting process. In some cases, the shape of the binding curve accurately defines the value of [S], because a relatively abrupt change in slope is observed at the 1:1 point (see below). However for titration data that were well below the tight binding limit, the concentration of protein binding sites cannot be determined accurately. In these cases, any value of [S] that is less than or equal to the actual value will provide an equally good fit to the binding isotherm. However in these cases, the fitted values of binding site concentration and fluorescence brightness directly compensate each other.

Therefore in order to compare the optical properties of different dyes bound to the protein, we use the parameter $I_{\text {bound }}$ shown in Eq 4. This parameter is well-defined in the fitting process, because variations in the fitted values of binding site concentration and fluorescence brightness directly compensate each other. Ibound corresponds to the fluorescence emission intensity that would be observed at a 1:2 stoichiometry of dye to protein binding sites, if all of the dye were fully bound to protein. In other words, $I_{\text {bound }}$ is the fluorescence emission intensity due to bound 
dye, when the concentration of free dye is equal to $K_{d}$ and half of the protein binding sites are occupied by dye.

$I_{\text {bound }}=\epsilon_{b} \phi_{b}[\mathrm{~S}] / 2 \quad$ Eq 4

In order to compare the optical properties of free and bound dye, we use the parameter $I_{\text {free }}$ shown in Eq 5. This parameter is also a well-defined in the fitting process, since accurate values of both $K_{d}$ and $\epsilon_{f} \phi_{f}$ can be obtained in all cases. Ifree corresponds to the fluorescence emission intensity that would be observed at a concentration of dye equal to dissociation constant for binding to the protein, if none of the dye were bound to protein. In other words, $I_{\text {free }}$ is the fluorescence emission intensity due to free dye, when the concentration of free dye is equal to $K_{d}$ and half of the protein binding sites are occupied by dye.

$I_{\text {free }}=\epsilon_{b} \phi_{b} K_{d} \quad$ Eq 5

Thus the ratio $I_{\text {bound }} / I_{\text {free }}$ is the amplification factor that describes the increase in fluorescence intensity of the dye due to binding to the protein.

Table S1. Dissociation constants $\left(K_{d}\right)$ and fluorescence amplification factors $\left(I_{\text {bound }} / I_{\text {free }}\right)$ from fluorescence titrations of $0.5 \mu \mathrm{M} \alpha$-syn fibrils at $\mathrm{pH} 7.4$ and $298 \mathrm{~K}$.

\begin{tabular}{cccc} 
Compound & Replicate & $\begin{array}{c}\boldsymbol{K}_{\boldsymbol{d}} \\
\mathbf{n M}\end{array}$ & $\boldsymbol{I}_{\text {bound }} / \mathbf{I}_{\text {free }}$ \\
ThT & 1 & 920 & 13 \\
& 2 & 766 & 17 \\
& 3 & 523 & 38 \\
\hline $\mathbf{1}$ & 1 & 78.6 & 553 \\
& 2 & 54.8 & 191 \\
\hline DOPC/1 1\% & 1 & 4.52 & 12 \\
& 2 & 4.24 & 8 \\
& 3 & 3.91 & 8 \\
\hline DOPC/1 10\% & 4 & 2.79 & 7 \\
\hline & 1 & 13.9 & 128 \\
& 2 & 15.8 & 101 \\
\hline
\end{tabular}




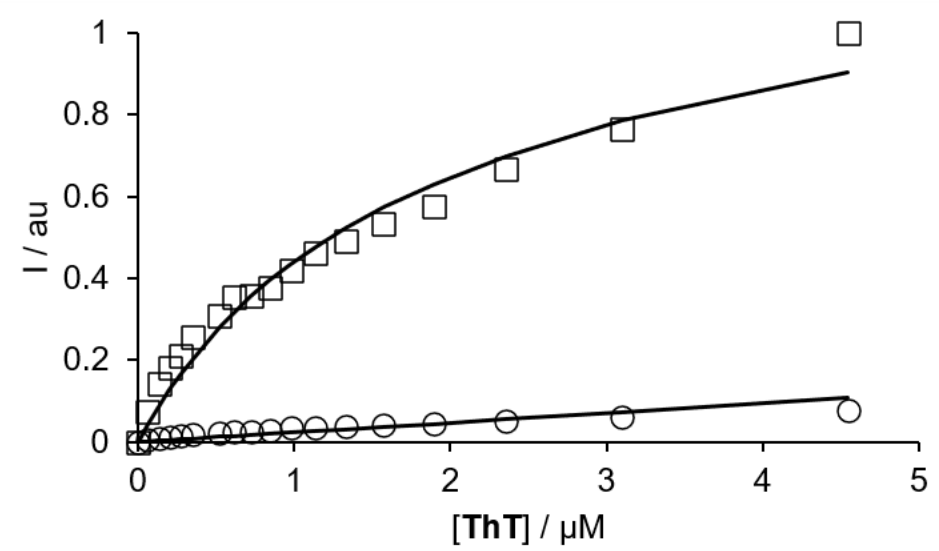

Figure S2. Fluorescence titration 1 uM Syn with increasing amounts of ThT. The squares are the data for a titration of a $1 \mu \mathrm{M}$ solution of $\alpha$-synuclein with increasing amounts of ThT. The spectra were recorded using $440 \mathrm{~nm}$ as excitation wavelength and using the emission spectra at $490 \mathrm{~nm}$. The circles are the fluorescence intensity at $490 \mathrm{~nm}$ for a titration of the dye into PBS buffer solution. The lines are the fitted data for both processes.

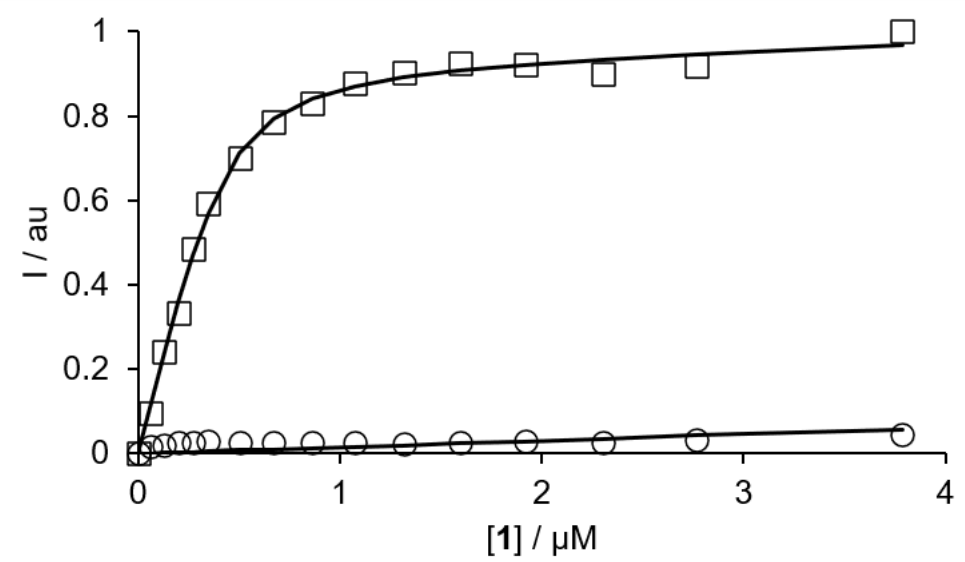

Figure S3. Fluorescence titration 0.5 uM Syn with increasing amounts of 1 . The squares are the data for a titration of a $0.1 \mu \mathrm{M}$ solution of $\alpha$-synuclein with increasing amounts of 1 . The spectra were recorded using $440 \mathrm{~nm}$ as excitation wavelength and using the emission spectra at $490 \mathrm{~nm}$. The circles are the fluorescence intensity at $490 \mathrm{~nm}$ for a titration of the dye into PBS buffer solution. The lines are the fitted data for both processes.

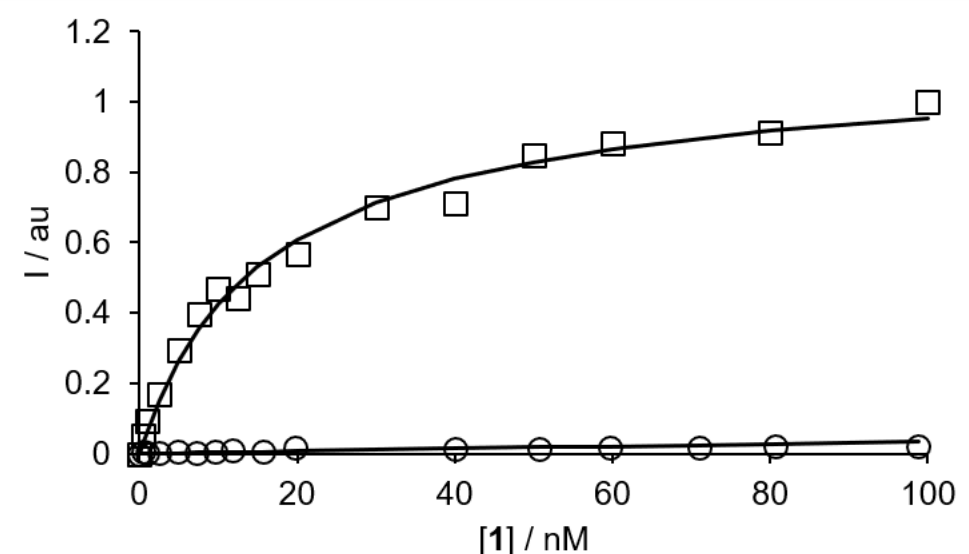

Figure S4. Fluorescence titration $0.1 \mathrm{uM}$ Syn with increasing amounts of DOPC vesicles containing a $10 \%$ of 1 . Every point has been recorded three hours after the addition of the dye. The squares are the data for a titration of a $0.1 \mu \mathrm{M}$ solution of $\alpha$-synuclein with increasing amounts of 1 . The spectra were recorded using $440 \mathrm{~nm}$ as excitation wavelength and using the emission spectra at $490 \mathrm{~nm}$. The circles are the fluorescence intensity at $490 \mathrm{~nm}$ for a titration of the dye into PBS buffer solution. The lines are the fitted data for both processes. 


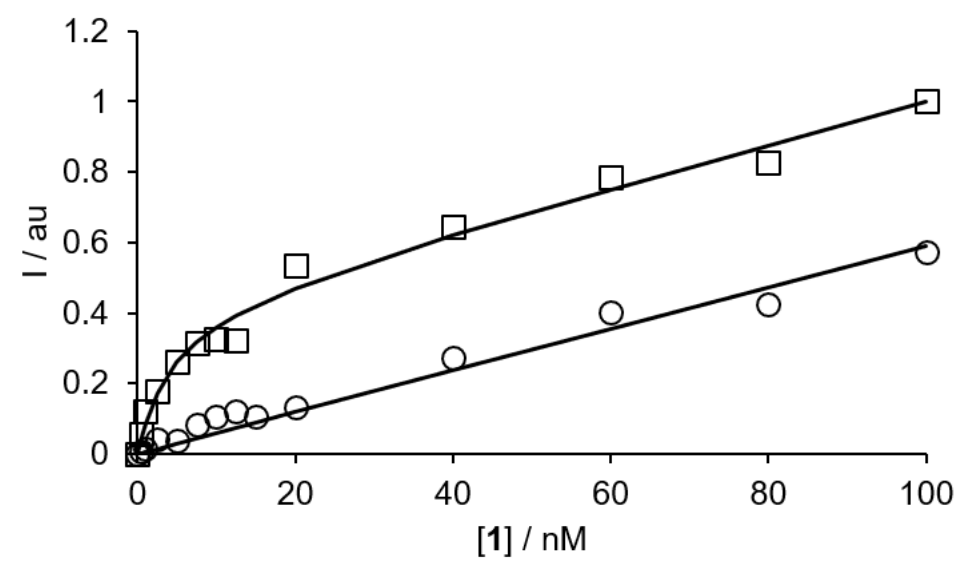

Figure S5. Fluorescence titration 0.1 uM Syn with increasing amounts of DOPC vesicles containing a $1 \%$ of 1 . Every point has been recorded three hours after the addition of the dye. The squares are the data for a titration of a $0.1 \mu \mathrm{M}$ solution of $\alpha$-synuclein with increasing amounts of 1 . The spectra were recorded using $440 \mathrm{~nm}$ as excitation wavelength and using the emission spectra at $490 \mathrm{~nm}$. The circles are the fluorescence intensity at $490 \mathrm{~nm}$ for a titration of the dye into PBS buffer solution. The lines are the fitted data for both processes.

\section{Kinetic studies}

In a typical experiment, stock solutions of $1(1 \mathrm{mM})$ in DMSO and $\alpha$-Synuclein $(10 \mu \mathrm{M})$ in PBS $1 \mathrm{X}$ $(\mathrm{pH} 7.4)$ were prepared. The concentration of $\alpha$-Synuclein was $0.1 \mu \mathrm{M}$ in all cases with different concentrations of DOPC $/ 1$ or 1 . Kinetics were carried out at $25^{\circ} \mathrm{C}$ using $20 \mathrm{~nm}$ slits. The excitation wavelength was $440 \mathrm{~nm}$ monitoring the emission at $490 \mathrm{~nm}$.

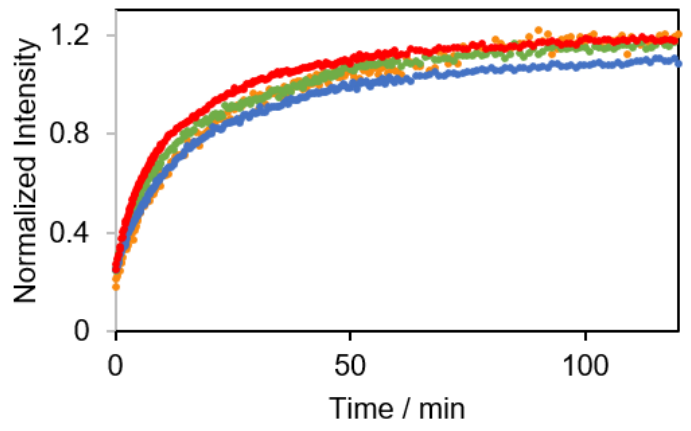

Figure S6. Normalized fluorescence intensity variation of a solution of $\alpha$-Synuclein $0.1 \mu \mathrm{M}$ with DOPC vesicles loaded with $10 \%$ of $\mathbf{1}$. The concentration of $\mathbf{1}$ is: $15 \mathrm{nM}$ (red), $7.5 \mathrm{nM}$ (blue), $5 \mathrm{nM}$ (green), $2.5 \mathrm{nM}$ (yellow). 


\section{Displacement assays}

$50 \mu \mathrm{M}$ stock solutions of ThT was prepared in DMSO. Vesicles were prepared by rehydrating a dry lipid film with a $10 \mathrm{mM}$ PBS solution at $\mathrm{pH}$ 7.4. After several freeze thaw cycles and extrusion through a $200 \mathrm{~nm}$ membrane, the vesicles suspension was passed through a size exclusion column and diluted to a final concentration of $1 \mathrm{mM}$. $0.17 \mathrm{~mL}$ of a $10 \mu \mathrm{M}$ stock solution of $\alpha$ synuclein amyloid was prepared in PBS 1X. Experiments were carried out at $25^{\circ} \mathrm{C}$ using $20 \mathrm{~nm}$ slits. The samples were prepared by dilution of the corresponding amount of stock solution in PBS 1X. For the displacement assay, first a $0.5 \mu \mathrm{M} \alpha$-Synuclein and $5 \mu \mathrm{M}$ ThT solution was prepared. After $5 \mathrm{~min}$, increasing amounts of DOPC vesicles solution containing $0.5 \mu \mathrm{M} \alpha$ Synuclein and $5 \mu \mathrm{M}$ ThT were added.

The fluorescence spectra were analysed using a Microsoft Excel spreadsheet to fit the changes in fluorescence intensity at fixed wavelengths to a 1:1 binding isotherm by optimizing the association constant and fluorescence intensity of the free and bound guest using purpose written VBA macros.

\section{TEM imaging}

Two hundred square mesh copper grids with continuous carbon film were freshly glowdischarged for $30 \mathrm{~min}$ before incubation with samples. $2 \mu \mathrm{L}$ of sample were applied and incubated for $30 \mathrm{~s}$ on a grid before blotting and staining with $2 \%(\mathrm{wt} / \mathrm{vol})$ uranyl acetate. TEM images were acquired using Talos F200X G2 electron microscope operating at $200 \mathrm{kV}$ using a single-tilt specimen holder.

\section{References}

1. Buell, A. K.; Galvagnion, C.; Gaspar, R.; Sparr, E.; Vendruscolo, M., Knowles, T. P. J.; Linse, S.; Dobson, C. M.; PNAS, 2014, 111, 7671-7676.

2. a) Ware, R. W.; Almond, M. R.; Lampert, B. M. PCT Int. Appl., 2012031045, 08 Mar 2012. b) Wang, H.; Huang, J.; Uddin, M.; Liu, B.; Chen, P.; Shi, S.; Tang, Y.; Xing, G.; Zhang, S.; Woo, H.; Guo, H.; Guo, X. ACS Applied Materials \& Interfaces 2019, 11, 10089-10098. 